\title{
ЕКОНОМІЧНА ДІАГНОСТИКА СТРАТЕГІЧНОГО УПРАВЛІННЯ ІМПОРТНОЮ ДІЯЛЬНІСТЮ ПІДПРИЕМСТВА ЯК УМОВА ЗАБЕЗПЕЧЕННЯ ЙОГО КОНКУРЕНТОСПРОМОЖНОСТІ
}

\section{ECONOMIC DIAGNOSTICS OF STRATEGIC MANAGEMENT OF AN ENTERPRISE'S IMPORT ACTIVITIES AS A CONDITION FOR ENSURING ITS COMPETITIVENESS}

\author{
Ковальчук Альона Миколаївна \\ кандидат економічних наук, доцент, \\ Національний авіаційний університет \\ ORCID: https://orcid.org/0000-0002-9059-8303 \\ Циганій Сергій Васильович \\ здобувач вищої освіти, \\ Національний авіаційний університет \\ ORCID: https://orcid.org/0000-0001-6239-3928
}

\author{
Kovalchuk Alona, Tsyhanii Serhii \\ National Aviation University
}

\begin{abstract}
У статті досліджено аспекти здійснення економічної діагностики стратегічного управління імпортною діяльністю підприємства, що впливає на забезпечення конкурентоспроможності. Актуальність дослідження визначається використанням інструментів імпортної діяльності вітчизняними підприємствами, засобу досягнення конкурентоспроможності. Визначено, що економічна діагностика $є$ одним із сучасних напрямів дослідження підприємства, який дозволяє швидко реагувати на зміни, адаптуватись до проблем та впливати на управлінські рішення у стратегічному вимірі. Встановлено, що ефективність стратегії управління підприємством залежить від оцінювання поточного та потенційних стану підприємства. Виявлено, що імпортна діяльність дозволяє отримати ряд конкурентних переваг для підприємства при стратегічному плануванні. Запропонована схема економічної діагностики стратегічного управління імпортною діяльністю підприємства.

Ключові слова: економічна діагностика, стратегія, стратегічне управління, конкурентоспроможність, підприємство, імпортна діяльність.
\end{abstract}

В статье исследованы аспекты осуществления экономической диагностики стратегического управления импортной деятельностью предприятия, что влияет на обеспечение конкурентоспособности. Актуальность исследования определяется использованием инструментов импортной деятельности отечественными предприятиями как средства достижения конкурентоспособности. Определено, что экономическая диагностика является одним из современных направлений исследования предприятия, позволяющего быстро реагировать на изменения, адаптироваться к проблемам и влиять на управленческие решения в стратегическом измерении. Установлено, что эффрективность стратегии управления предприятием зависит от оценки текущего и потенциального состояния предприятия. Выявлено, что импортная деятельность позволяет получить ряд конкурентных преимуществ предприятий при стратегическом планировании. Предложена схема экономической диагностики стратегического управления импортной деятельностью предприятия.

Ключевые слова: экономическая диагностика, стратегия, стратегическое управление, конкурентоспособность, предприятие, импортная деятельность.

In article aspects of realization of economic diagnostics of strategic management of import activity of enterprise which influences on maintenance of competitiveness are investigated. The relevance of the study is determined by the use of tools of import activities by domestic enterprises as a means of achieving competitiveness. Methods of research: systematization for revealing main tendencies of strategic management of enterprises in competitive environment; comparison for revealing methods and business-indicators of economic diagnostics of strategic ma- 
nagement of import activities; generalization and abstract-logical for revealing of the main results, formation of the conclusions of the conducted research. The purpose of the article is to investigate peculiarities of economic diagnostics of strategic management of import activities of enterprise as a condition of its competitiveness in the modern variable-adaptive space of functioning of domestic enterprises. It was determined that economic diagnostics is one of the modern areas of enterprise research, which allows to respond quickly to changes, adapt to problems and influence management decisions in the strategic dimension. It was found that the effectiveness of enterprise management strategy depends on the evaluation of the current and potential state of the enterprise. It has been revealed that imported activities allow for a number of competitive advantages at the enterprise in the strategic management. The scheme of economic diagnostics of strategic management of import activity of enterprise is offered. The basic directions of economic diagnostics of strategic management of import activity of enterprise are singled out: type of development, basic activity of enterprise, personnel and management, property maintenance of possible import, technical maintenance, financial condition, market opportunities, import practice, enterprise strategy, competitive environment, competitiveness. The practical value of the study consists in the possibilities of application of the proposed scheme of economic diagnostics of strategic management of enterprise import activities. At the same time, enterprises can use this scheme to diagnose the level of competitiveness.

Keywords: economic diagnosis, strategy, strategic management, competitiveness, enterprise, import activities.

Постановка проблеми. Діяльність підприємств ускладняються у зв'язку із трансфрормаціями середовища їх функціонування та трансорормаціями які відбуваються нині та мають постійно-змінний характер. Підприємства, які прагнуть розвиватись та займати відповідну позицію на конкурентних ринках фрункціонують відповідно до заданого стратегічного напряму, використовуючи інструменти стратегічного управління, яке має ґрунтуватись на якісній економічній діагностиці усіх систем забезпечення його діяльності та усіх результативних показників. Для вітчизняних підприємств, які прагнуть забезпечити належний рівень конкурентоспроможності одним із напрямів $€$ імпортна діяльність, яка підлягає діагностуванню та, як правило, є частиною стратегічних планів підприємств. Таким чином, трансформаційні процеси у економічному середовищі зумовлюють необхідність використання економічної діагностики стратегічного управління імпортною діяльністю підприємства, що сприятиме досягнення ними належного рівня конкурентоспроможності.

Аналіз останніх досліджень і публікацій Проблеми здійснення економічної діагностики діяльності підприємств були предметом досліджень вітчизняних науковців: Тульчинська С., Кухарчук I. [1], Арефр'єва О., Вовк О. [2], Бойко В. [3] та інші. Стратегічне управління підприємством, як інструмент досягнення його конкурентних переваг досліджували: Арефр'єва О., Побережна 3. [4], Терещенко І., Білецька Д. [9], Вовк О. [5], Пілецька С., Ткаченко Є. [6], Величко Т. [10], Прохорова В., Проценко В., Чобіток В [8] та інші. Проте, незважаючи на поглиблені дослідження стратегічного управління та економічної діагностики діяльності підприємств саме діагностика стратегічного управління імпортною діяльністю потребує поглибленого аналізу та обґрунтування, оскільки дозволяє підприємствам набувати конкретних переваг у мінливому ринковому середовищі.

Постановка завдання. Метою статті $\epsilon$ дослідження особливостей економічної діагностики стратегічного управління імпортною діяльністю підприємства як умови забезпечення його конкурентоспроможності в сучасному змінно-адаптивному просторі фрункціонування вітчизняних підприємств.

Викладення основного матеріалу. У сучасних динамічних умовах ведення господарської діяльності методологія економічної діагностики $€$ актуальним напрямом дослідження стану підприємства. Економічна діагностика $€$ оцінкою економічних показників роботи підприємства, яка здійснюється на основі вивчення окремих результатів та неповної інформації з метою виявлення можливих перспектив його розвитку, наслідків ухвалення поточних управлінських рішень. Підсумком діагностики можуть бути ґрунтовні висновки, необхідні для прийняття термінових важливих рішень. Економічна діагностика $\epsilon$ невід'ємною складовою системи управління кожного підприємства, так як спрямована на ідентифрікацію минулого, поточного та перспективного стану, розробку превентивних, санаційних і реактивних управлінських рішень, які спрямовані на виявлення та ліквідацію проблем [1]. Економічну діагностику слід розглядати як окрему галузь оцінки та аналізу стану та діяльності підприємства як окремої господарської одиниці для своєчасного виявлення та усунення проблем [2], при цьому враховуючи фрактори, що впливають на діяльність підприємств[3]. Тобто, економічна діагностика $€$ одним із сучасних 
напрямів дослідження підприємства, який дозволяє швидко реагувати на зміни, адаптуватись до проблем та впливати на управлінські рішення. Оскільки імпортна діяльність пов'язана із значними ризиками та проблемами, то саме інструменти економічної діагностики дозволять адаптувати їі до сучасних вимог ведення бізнесу. Водночас економічна діагностика $€$ дієвим інструментом стратегічного управління, оскільки дозволяє оцінити минулі, поточні та майбутні показники діяльності підприємства.

Для забезпечення та підтримки ефективної діяльності підприємства у конкурентному середовищі та утримання конкурентоспроможності необхідне систематичне та безперервне управління його бізнес-процесами. Якісно розроблена стратегія дозволить підприємству досягнути запланованих результатів будь якої діяльності (у т.ч. й імпортної) у довгостроковій перспективі. Процедура стратегічного управління бізнес-процесами розвитку підприємства дозволяє організувати та втілити комплексний підхід, який буде включати необхідну економічну діагностику. Інструменти стратегічного управління сприяють прийняттю управлінських рішень щодо реалізації розвитку на основі бізнес-процесів, узгоджених зі стратегічними цілями [4]. Економічна діагностика стратегічного управління підприємства дозволить вносити корективи у стратегії підприємств на основі уже реалізованих поточних заходів прийнятих стратегій та відповідно до нових умов конкурентного середовища.

Концепція управління стратегічним розвитком підприємства виражається в таких особливостях застосування:

- взаємозв'язку системного, ситуаційного та цільового підходів до діагностування діяльності організації;

- визначення умов, в яких здійснює діяльність підприємство та ідентиорікація основних фракторів впливу;

- застосування відповідного інструментарію і методичного забезпечення діагностування розвитку підприємств: цілей, «дерева цілей», стратегій, «стратегічного набору», стратегічних планів, програм, стратегічного планування;

- необхідність узагальнення, систематизації, актуалізації та встановлення пріоритетності інсрормації;

- проектування змін та виявлення фрорм і напрямів впливу підприємства на результативність змін [5].
Для розробки есрективної стратегії потрібно вивчення ринкової позиції підприємства, оцінки потенційних можливостей та ризиків, а також аналіз фрінансово-господарського стану, досягнутого рівня ефективності управління підприємством, прогнозування змін кон'юнктури ринку тощо [6]. Тобто, ефрективність стратегії управління підприємством залежить від оцінювання поточного та потенційних стану підприємства, його основних видів діяльності, які в першу чергу дозволять набути особливих конкурентних переваг, таке оцінювання забезпечить наявність на підприємстві системи економічної діагностики.

Оскільки для ряду підприємств імпортна діяльність $€$ ключовим бізнес-процесом, який забезпечує його конкурентоспроможність, то при здійснені стратегічного управління необхідно враховувати ії особливості, здійснювати діагностику основних показників. Економічна діагностика стратегічного управління імпортною діяльністю потребує пояснення ї сутності, Манаєнко І. та Таран В. розглядають імпортну діяльність як «сукупність взаємозалежних дій щодо купівлі продукції суб'єктами підприємництва певної країни у зарубіжного контрагента 3 метою ії̈ подальшої реалізації та споживання на території країни-імпортера» [7]. Імпортна діяльність, особливо як об'єкт стратегічного управління дозволяє отримати ряд конкурентних переваг, які наведено на рис. 1.

Конкурентні переваги, що підприємство набуде за здійснення імпортної діяльності дозволяють йому сорормувати конкурентну стратегію, яка $€$ векторним розвитком підприємства, що складається із стратегічних цілей та напрямів, які фоормуються управлінцями, виходячи із теперішньої позиції підприємства на конкурентному ринку, наявних у нього переваг (початкової точки) й темпу їх зміни та закінчується досягненням поставлених цілей [9]. Формування конкурентної стратегії, досягнення конкурентних переваг та необхідність стратегічного управління імпортною діяльністю на підприємстві зумовлює використання інструментів та методології економічної діагностики при цьому.

Для пояснення досягнення належного рівня стратегічного управління імпортною діяльністю пропонуємо розглянути схему економічної діагностики стратегічного управління імпортною діяльністю підприємства (рис. 2).

Дана схема складається із напрямів економічної діагностики, методів та бізнес-індикаторів, що дозволять максимально ефективно дослідити усі аспекти стратегічного 
розширення існуючого асортименту товарів, що дозволить підприємству запропонувати більше продукції на продаж;

можливість придбання більш якісних сировинних ресурсів, матеріалів, комплектуючих, технологій за нижчою ціною;

\begin{tabular}{|c|}
\hline мінімізація операційних ризиків, так як підприємство може розширити коло \\
постачальників, і як наслідок має меншу залежність від тиску єдиного постачальника; \\
\hline забезпечення сприятливого іміджу підприємства на внутрішньому ринку шляхом імпорту \\
більш якісних іноземних товарів; \\
\hline пншжекння виробничих витрат шляхом імпорту готових товарів замість їх виробництва \\
на власних потужностях; \\
\hline розвиток нових технологій внаслідок імпорту наукомістких товарів \\
\hline
\end{tabular}

Рис. 1. Конкурентні переваги імпортної діяльності підприємств у стратегічному вимірі Джерело: побудовано на основі [7; 8]

управління імпортною діяльністю підприємства сорормувавши рекомендації щодо коригування стратегічного управління імпортною діяльністю підприємства для підвищення його конкурентоспроможності.

Стратегічне управління імпортною діяльністю, його ефективне діагностування дозволить підприємству не лише досягнути належного рівня конкурентоспроможності, але й забезпечити сталий розвиток. Можливості для вдосконалення та підтримки сталого розвитку можуть мати різну спрямованість та дозволяють удосконалюватися шляхом освоєння нових видів продукції, розширення ринків збуту, інноваційного покращення існуючих технологій виробництва продукції, поліпшення умов праці робітників, створення загального сприятливого клімату та активізації мотивуючих заходів. Якщо підприємство стає на шлях досягнення сталого розвитку, це означає, що воно налаштоване на безупинне вдосконалення своєї діяльності та зміцнення внутрішнього потенціалу [10]. Вважаємо, що економічна діагностика стратегічного управління імпортною діяльністю дозволить підприємствам забезпечити та підтримувати сталий розвиток при цьому використовувати конкурентні переваги імпортної діяльності, які будуть підлягати постійному діагностуванню задля виявлення проблем і напрямів їх усунення.

Висновки. Таким чином, стратегічне управління імпортною діяльністю підприємства потребує використання методів економічної діагностики, які дозволять адаптувати цілі та завдання такої діяльності у тактичному та стратегічному вимірі. Зауважимо, що ефрективність напрямів стратегії управління підприємством (в т.ч. й імпортної діяльності) залежить від оцінювання поточного та потенційних стану підприємства. Дослідження свідчать, що імпортна діяльність дозволяє отримати ряд конкурентних переваг для підприємства, тому доцільно використовувати саме інструменти стратегічного управління, оскільки конкурентні переваги мають стратегічний характер. В результаті дослідження запропонована схема економічної діагностики стратегічного управління імпортною діяльністю підприємства, відповідно до якої економічну діагностику на підприємстві слід здійснювати за визначеними напрямами, методами та бізнес-індикаторами. Подальші дослідження будуть спрямовані на практичне використання даної схеми на вітчизняних підприємствах. 


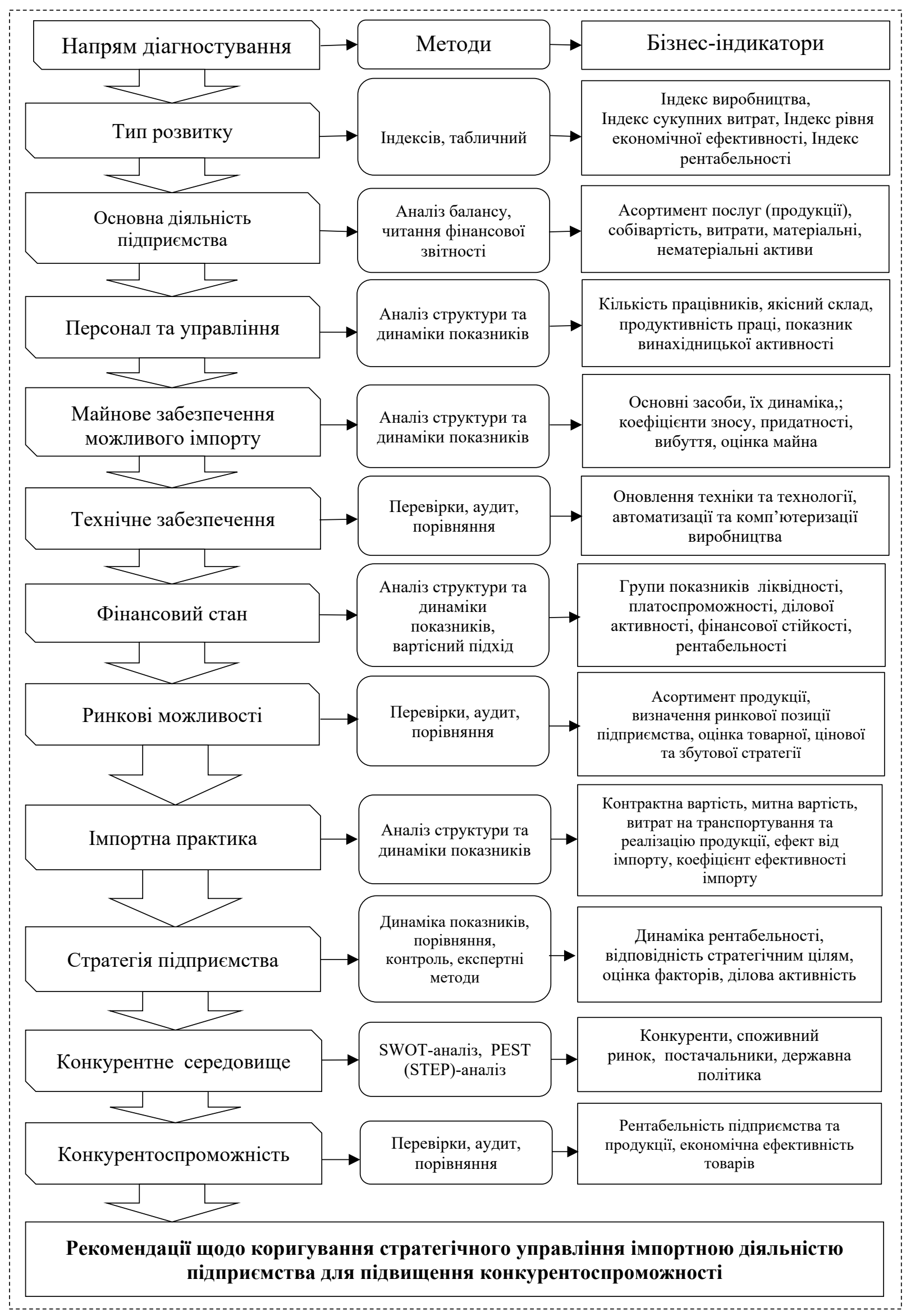

Рис. 2. Схема економічної діагностики стратегічного управління імпортною діяльністю підприємства 


\section{СПИСОК ВИКОРИСТАНИХ ДЖЕРЕЛ:}

1. Тульчинська С.О., Кухарчук І.Л. Економічна діагностика виробничо-господарської діяльності підприємства. Сучасні проблеми економіки і підприємництво : збірник наукових праць. 2013. Вип. 11. С. 299-305.

2. Ареср'єва О.В., Вовк О.М. Адаптивне управління підприємствами в умовах неотехнологічного відтворення : монографія. Київ : НАУ, 2020. 232 с

3. Бойко В.В. Сучасні тенденції розвитку економічної діагностики стану підприємств. Економіка та управління на транспорті. 2017. № 4. С. 18-24.

4. Ареф'єва О.В., Побережна 3.М. Стратегічне управління інноваційністю бізнес-процесів підприємства на конкурентних ринках. Бізнес Інформ. 2019. № 11. С. 108-116.

5. Вовк О.М., Ковальчук А.М. Стратегічне управління розвитком підприємств в умовах конкурентної економіки. Збірник наукових праць Університету державної фіскальної служби України. 2019. № 1. С. 20-32. DOI: https://doi.org/10.33244/2617-5940.1.2019.20-32

6. Пілецька С.Т., Ткаченко Є.В. Формування стратегії інноваційного розвитку підприємства. Економічні cmydiï. 2020. № 1. C. 146-150.

7. Манаєнко І.М., Таран В.В. Розвиток імпортної діяльності підприємства. Збірник наукових праць «Сучасні підходи до управління підприємством». 2019. № 4. С. 211-220.

8. Прохорова В.В., Проценко В.М., Чобіток В.І. Формування конкурентної стратегії підприємств на засадах інноваційно-спрямованого інвестування : монограсрія / Укр. інж.-пед. акад. Херсон : Грінь Д.С. [вид.], 2016. 287 с.

9. Терещенко І.О., Білецька Д.І. Конкурентні стратегії управління підприємством. Агросвіт. 2019. № 20. C. 82-87. DOI: https://doi.org/10.32702/2306-6792.2019.20.82

10. Величко Т.Г. Основні напрями стратегічного управління підприємством в умовах сталого розвитку. Агросвіт. 2020. № 7. C. 92-96. DOI: https://doi.org/10.32702/2306-6792.2020.7.92

\section{REFERENCES:}

1. Tulchynska S.O., Kukharchuk I.L. (2013) Ekonomichna diahnostyka vyrobnycho-hospodars'koyi diyal'nosti pidpryyemstva [Economic diagnostics of production and economic activity of the enterprise]. Suchasni problemy ekonomiky i pidpryyemnytstvo - Modern problems of economics and entrepreneurship, 11, 299-305. (in Ukrainian)

2. Arefieva O.V., Vovk O.M. (2020) Adaptyvne upravlinnya pidpryyemstvamy $v$ umovakh neotekhnolohichnoho vidtvorennya: monohrafiya [Adaptive management of enterprises in terms of neotechnological reproduction: a monograph]. Kyiv: NAU. (in Ukrainian)

3. Boyko V.V. (2017) Suchasni tendentsiyi rozvytku ekonomichnoyi diahnostyky stanu pidpryyemstv [Current trends in the development of economic diagnostics of enterprises]. Ekonomika ta upravlinnya na transporti Economics and Management in Transport, 4, 18-24. (in Ukrainian)

4. Arefieva O.V., Poberezhna Z.M. (2019) Stratehichne upravlinnya innovatsiynistyu biznes-protsesiv pidpryyemstva na konkurentnykh rynkakh [Strategic management of innovation of business processes of the enterprise in competitive markets]. Biznes Inform - Business Inform, 11, 108-116.

5. Vovk O.M., Kovalchuk A.M. (2019) Stratehichne upravlinnya rozvytkom pidpryyemstv v umovakh konkurentnoyi ekonomiky [Strategic management of development of enterprises in the conditions of competitive economy]. Zbirnyk naukovykh prats' Universytetu derzhavnoyi fiskal'noyi sluzhby Ukrayiny - Collection of scientific works of the University of the State Fiscal Service of Ukraine, 1, 20-32. DOI: https://doi.org/10.33244/2617-5940.1.2019.20-32 (in Ukrainian)

6. Piletskaya S.T., Tkachenko E.V. (2020) Formuvannya stratehiyi innovatsiynoho rozvytku pidpryyemstva [Formation of the strategy of innovative development of the enterprise]. Ekonomichni studiyi - Economic Studies, 1, 146-150. (in Ukrainian)

7. Manaenko I.M., Taran V.V. (2019) Rozvytok importnoyi diyal'nosti pidpryyemstva [Development of import activity of the enterprise]. Zbirnyk naukovykh prats "Suchasni pidkhody do upravlinnya pidpryyemstvom" - Collection of scientific works "Modern approaches to enterprise management", 4, 211-220. (in Ukrainian)

8. Prokhorova V.V., Protsenko V.M.,. Chobitok V.I. (2016) Formuvannia konkurentnoi stratehii pidpryiemstv na zasadakh innovatsiino-spriamovanoho investuvannia [Formation of competitive strategy of enterprises on the basis of innovation-oriented investment]: monohrafiia. Ukr. inzh.-ped. akad. Kherson: Hrin D.S. (in Ukrainian)

9. Tereshchenko I.O., Biletskaya D.I. (2019) Konkurentni stratehiyi upravlinnya pidpryyemstvom [Competitive strategies of enterprise management]. Ahrosvit - Agrosvit, 20, 82-87. DOI: https://doi.org/10.32702/2306-6792.20 19.20.82 (in Ukrainian)

10. Velichko T. (2020) Osnovni napryamy stratehichnoho upravlinnya pidpryyemstvom v umovakh staloho rozvytku [The main directions of strategic management of the enterprise in the conditions of sustainable development]. Ahrosvit - Agrosvit, 7, 92-96. DOI: https://doi.org/10.32702/2306-6792.2020.7.92 (in Ukrainian) 